SCIREA Journal of Geosciences

http://www.scirea.org/journal/Geosciences

February 24, 2022

Volume 6, Issue 1, February 2022

https://doi.org/10.54647/geosciences 17152

\title{
Spontaneous Frequency Polarisation (SFP) method application for mapping mineral deposits in the metamorphic sedimentary formations in the Bidzar area (North-Cameroon)
}

\author{
Daniel Hervé Gouet ${ }^{1^{*}}$, Marcelin Bikoro Bialou ${ }^{2}$ and Arsène Meying ${ }^{3}$ \\ ${ }^{1}$ Department of Mines, Oil, Gas and Water Resources Exploration, Faculty of Mines and \\ Petroleum Industries, University of Maroua, P.O. Box 08 Kaélé, Far North - Cameroon \\ ${ }^{2}$ Department of Earth Sciences, Faculty of Science, University of Maroua, P.O. Box 46 \\ Maroua, Cameroun \\ ${ }^{3}$ Department of Applied Geophysics, School of Geology and Mining Engineering, University \\ of Ngaoundere, P.O. Box 115 Meiganga, Cameroon \\ ${ }^{*}$ Corresponding author: gouetdanyl@yahoo.fr
}

\begin{abstract}
The North Cameroon (Central Africa) region rests on Precambrian metamorphic rocks dating. In the areas covered by metamorphic sedimentary formations, this region conceals a significant mineral potential. The geological and geochemical works carried out in the study area permitted to analyze the mineralogy of the formations in place and to map the formations with good potential in useful minerals. This work, using the hammer prospecting technique, mapped the marble identified as the local commodity. A geophysical study using the ElectroTelluric or Spontaneous Frequency Polarization (SFP) method was carried out to evaluate the
\end{abstract}


electrical parameters of the surface formations, particularly those of the ore in the Bidzar area. This study is based on a set of fifty-five (55) profiles, NW-SE direction, inter-profile distance one hundred (100) meters and length varying between $1 \mathrm{~km}$ and $2.2 \mathrm{~km}$. The geophysical surveys are carried out at a step of fifty (50) meters using a PQWT500 geoelectrical device from the Hunan Puqi Institute (China). The results of this study show that the Bidzar marble ore is a network of lenticular corridors trending NE-SW. These corridors are mainly characterized by high electrical gradients $(\mathrm{ddp}>3 \mathrm{mV})$. They alternate with schist or sterile rocks of relatively low electrical gradients (ddp $<3 \mathrm{mV}$ ). The comparison of the abovementioned results with the geological results of hammer prospecting and the borehole data show a perfect correlation of the electrical responses (ddp) with the geological formations in place. Thus, it confirms the validity of the spontaneous frequency polarization (SFP) method in the mapping of ores from metasedimentary formations, particularly those of the marble type.

Keywords: Electro-telluric, cartography, marble, electric gradient, lenticular corridors

\section{Introduction}

Cameroon's industrial capacities depend mainly on its mineral potential which necessitates the evaluation of the mineral resources of each of its regions. The mining potential of the North Cameroon region of Central Africa is characterized mainly by the mineral resource by marble a raw material for cement factories. According to Lafarge group standards in Cameroon, the opening of a cement plant requires at least 50 years of operation, which corresponds to a reserve of 30 million tonnes. For this, a rational estimate of the marble operating cycle must be carried out for a rational forecast of the group's expectations. So, exploration works (mainly in geology and geophysics) must be carried out before any planned exploitation of the deposit. Thus, the present geophysical investigation, based on the results of the geological work, was carried out in Bidzar, in order to get an idea of the deployment of the marble ore and its intrinsic electrical parameters.

In this study area we focus on geoelectrical methods, those that measure electrical telluric current especially Telluric or spontaneous frequency polarization method. We do so because the mineral deposits characterize typically by their electrical response in the metamorphic sedimentary formations [1]. The electrical response or electrical gradient (ddp) of a geologic unit, in general, reflects its lithology, its porosity, and the saturation and conductivity of its 
pore water [1]. A unit consisting of crushed rock will have higher porosity than uncrushed; this means potentially higher pore water content to carry electrical currents through the unit [1].

The study area is located in the Bidzar village of the Mayo-Louti division, North Cameroon region (Figure 1). It covers an area between the E398000 m and E41000 m longitudes and the N1090000 m and N110000 m latitudes in the UTM 33N, WGS84 grid. The region's climate is Sudano-Sahelian with an average thermal amplitude of $26^{\circ} \mathrm{C}$. The vegetation is typical of the Sudano - Sahelian bushy savannah domain, characterized by a sparse bushy savannah dotted with thorny shrubs. The altitude varies between $327 \mathrm{~m}$ and $453 \mathrm{~m}$ but the lowest are found at the level of the mayo (seasonal stream). The drainage consists mainly of seasonal rivers (mayo) which flow mainly in the direction of large fractures and flow into the Mayo-Louti and Mayo-Figuil which are tributaries of the Benoue (Figure 1).

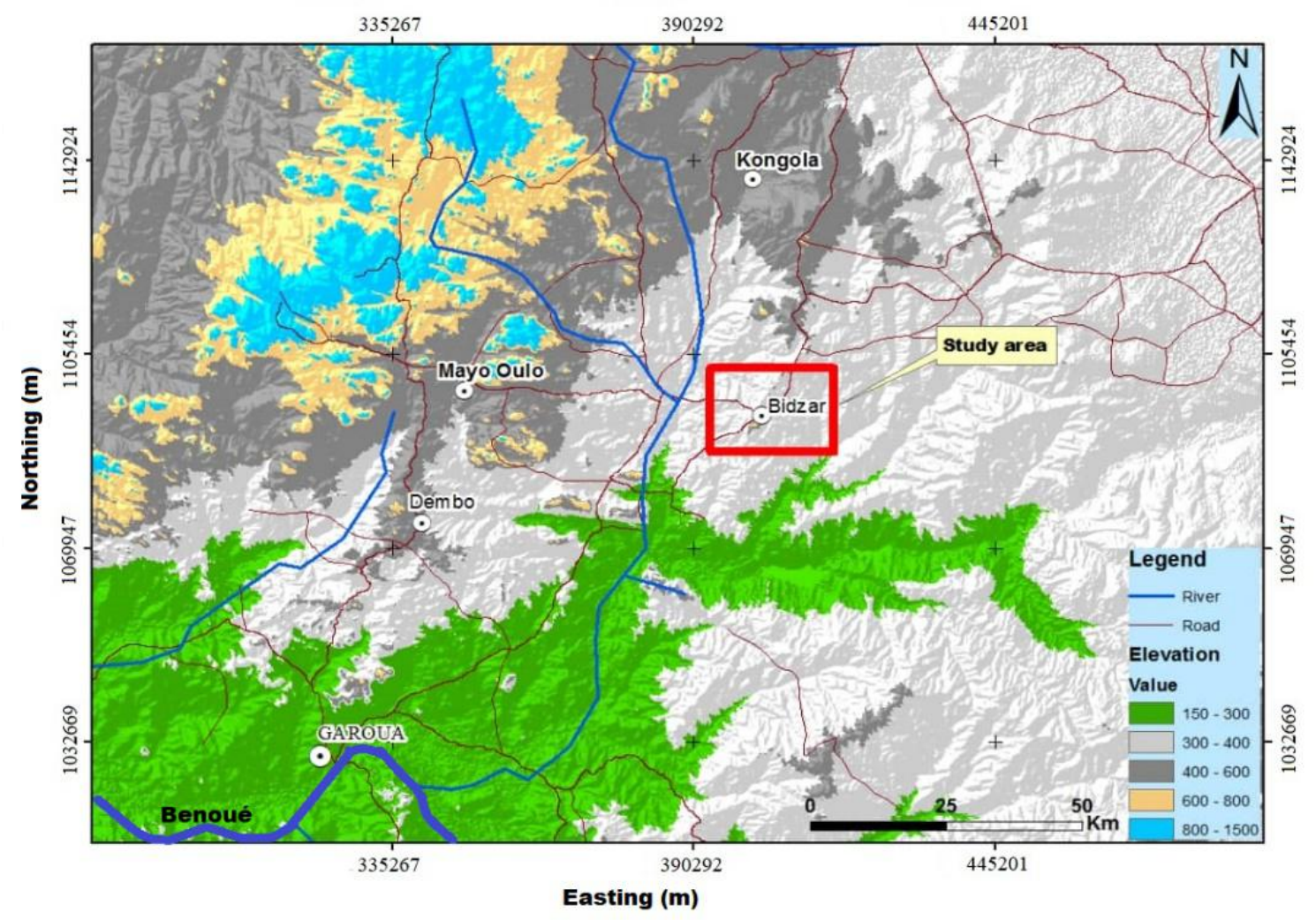

Figure 1. Location map of the study area

\section{Geological and tectonic setting}

\subsection{Geological structures and mineralization}

Two large groups of formations cover the North Cameroon region: the Precambrian basement of mainly Pan-African age and the sedimentary and volcanic formations of the synclinal 
Cretaceous basin of Babouri-Figuil [2]. The Precambrian basement is represented by granitoids and metavolcano-sedimentary formations. The Bidzar marble ore rests on a bedrock of metamorphic rocks dating from the Precambrian [3] [4].

According to geological and tectonic studies, the paragenesis of marble ore is probably linked to five successive major events [2] [3] [4] [5] [6]:

1. Opening and deposition of intercalations of clay (terrigenous) and limestone (precipitation) defining a horizontal stratification during the Precambrian. The thickness of the sediment sequence favoured diagenesis and possible partial mixing;

2. The Pan-African $(565 \pm 22 \mathrm{Ma})$ leading to the formation of large weakness zones (fractures) oriented NE - SW, is positively correlated with the Central African shear zone, the Sanaga fault and the Cameroon Volcanic Line. This event distorted the pre-existing sediments giving them a NE - SW direction.

3. Original horizontal deformation (folding and fault) and sediments fractured / faulted by "granitic pluton" plutonism. This event was linked to a thermal change (green schist facies) leading to the transformation of clays (schist) and limestone respectively into schist and marble (Figure 2) reaching the green schist facies (para isochemical metamorphism). This turned the original stratification (So) of the layers into a sub-vertical dip;

4. Erosion (much more chemical) of metasediments and the outcrop of "granitic pluton";

5. Subsequent deformation associated with tensile and compressive forces, modifying the pluton and defining a flower structure 


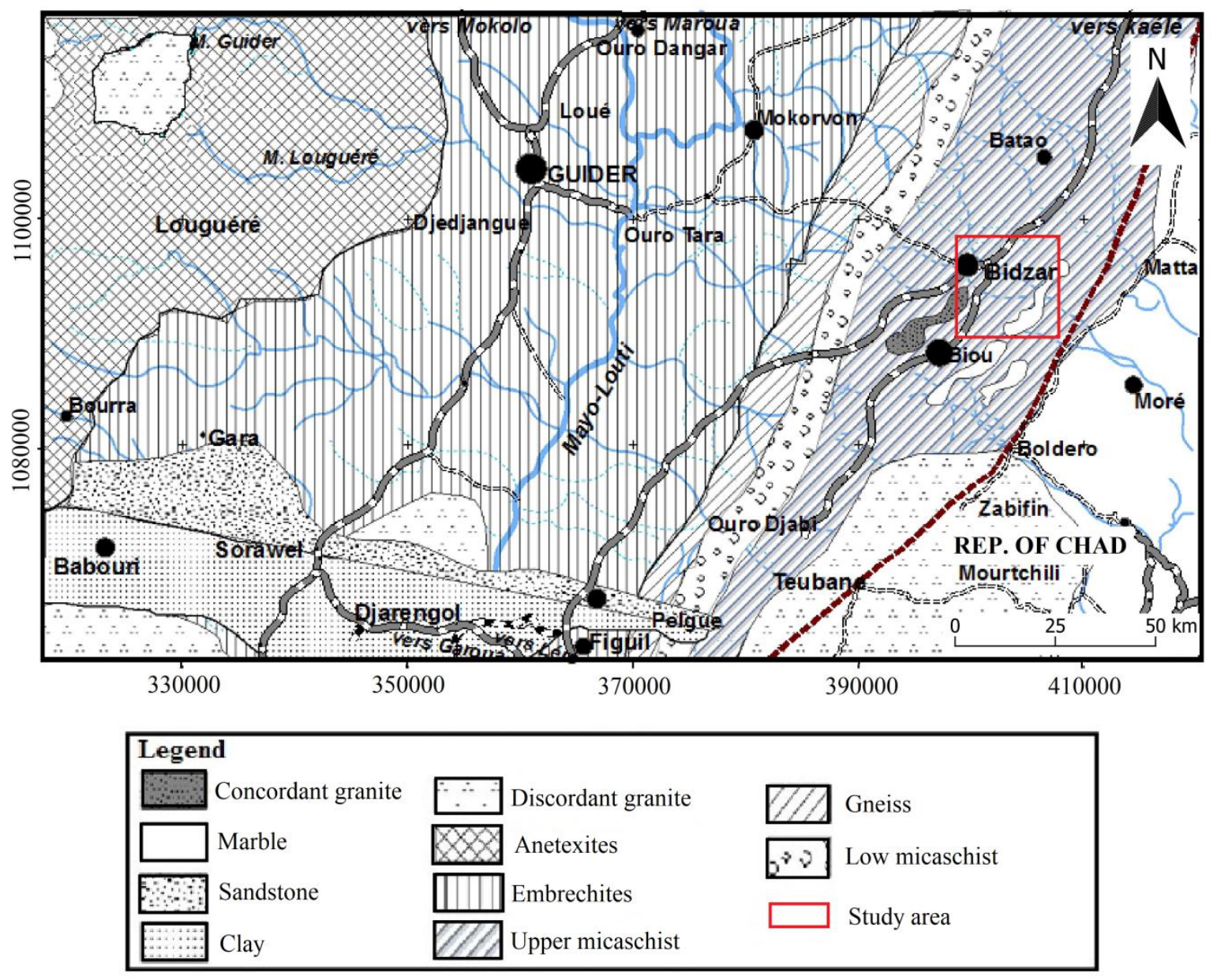

Figure 2. Geological map of the Mayo-Louti division and the study area [6]

\subsection{Geological mapping}

The geological mapping was carried out by some geologists during the field trips. They completely covered the study area using a specific technique of mining prospecting: hammer prospecting. It emerges from this technique that the study area essentially consists of schists, marbles, granites and a few occurrences of quartzites. The structural measurements carried out on the various marble outcrops show that the latter are mainly oriented NE-SW. These outcrops are fractured, faulted and folded in places. The stresses involved have led the layers to dip vertically to subvertically $\left(70^{\circ}\right.$ to $80^{\circ}$ ) in preferential ESE and SE directions. The geological reconnaissance work resulted into the production of a geological map of the study area (Figure 3). 


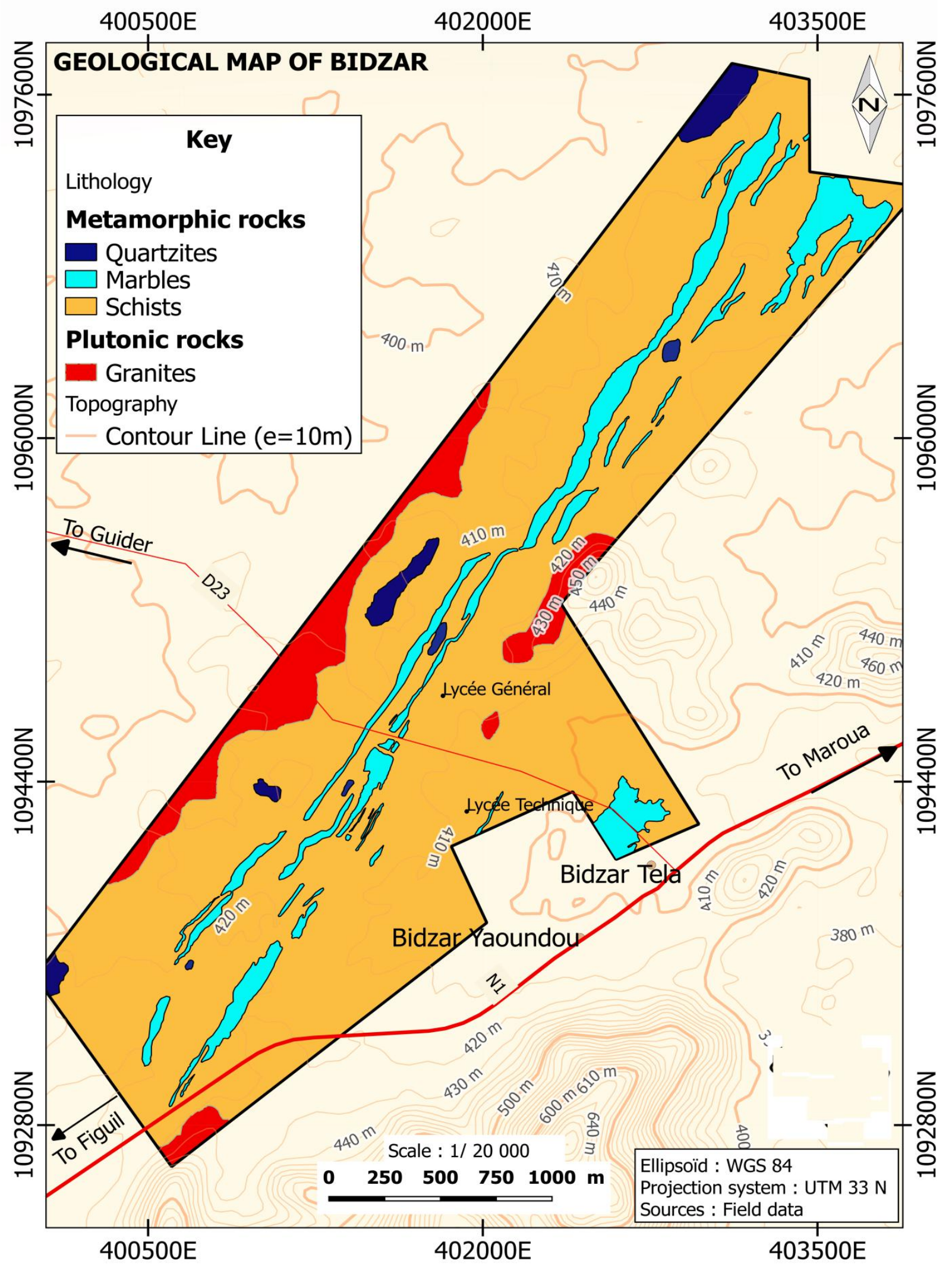

Figure 3. Geological map of marble outcrops of the study area 


\section{Materials and Method}

\subsection{Materials}

The geophysical working equipment consists of a PQWT500 device from the Hunan Puqi Institute (China) for spontaneous potential (ddp) measurements (Figure 4), and a Garmin GPS for the geographical location of the measurement stations.

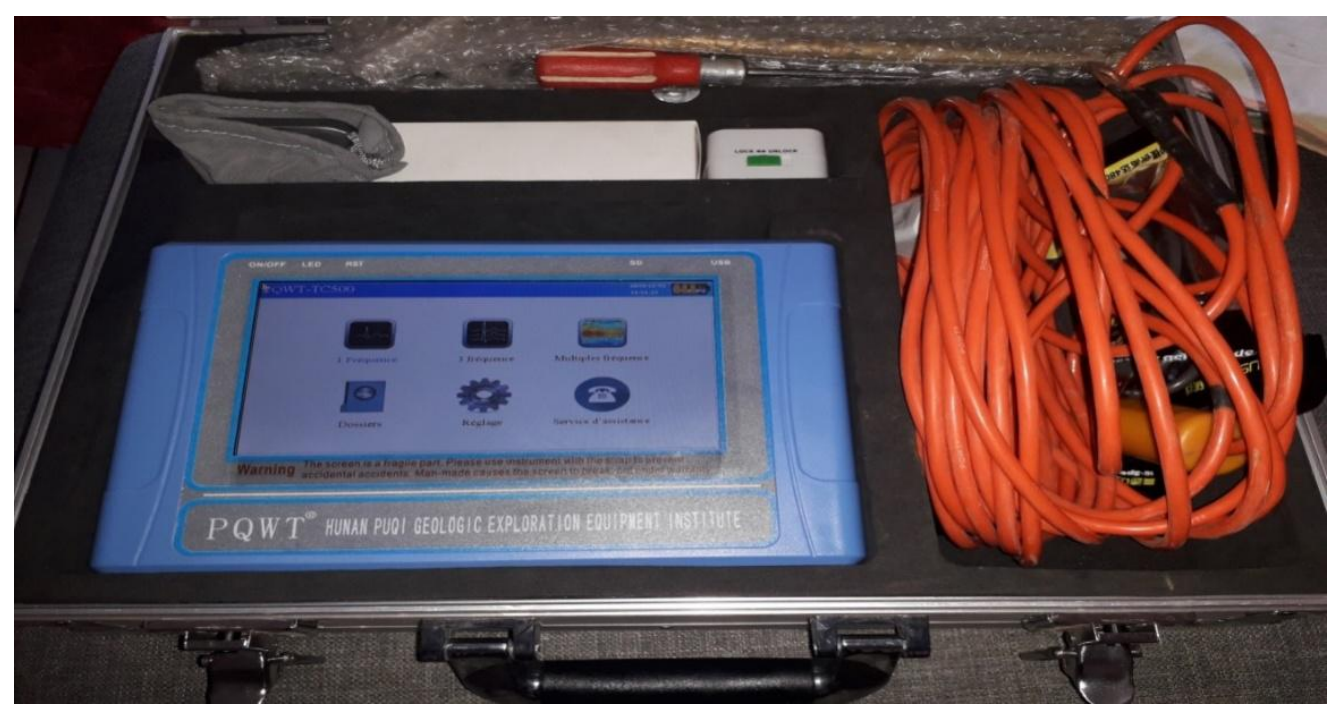

Figure 4. Geophysical exploration equipment PQWT500

The spontaneous potential (ddp) measurements was acquired on a set of fifty-five (55) profiles (length varying between $1 \mathrm{~km}$ and $2.2 \mathrm{~km}$ ), NW-SE directed and constantly distant of one hundred (100) meters (Figure 5). The measurements are taken in a step of fifty (50) meters. The point of measurement is the middle of the AM dipole which moves along the profile according to the gradients technique of measuring in SP $[1,7]$. In the field, a large number of one-off potential measurements are thus carried out in order to establish a profile and imagery of the study area. 


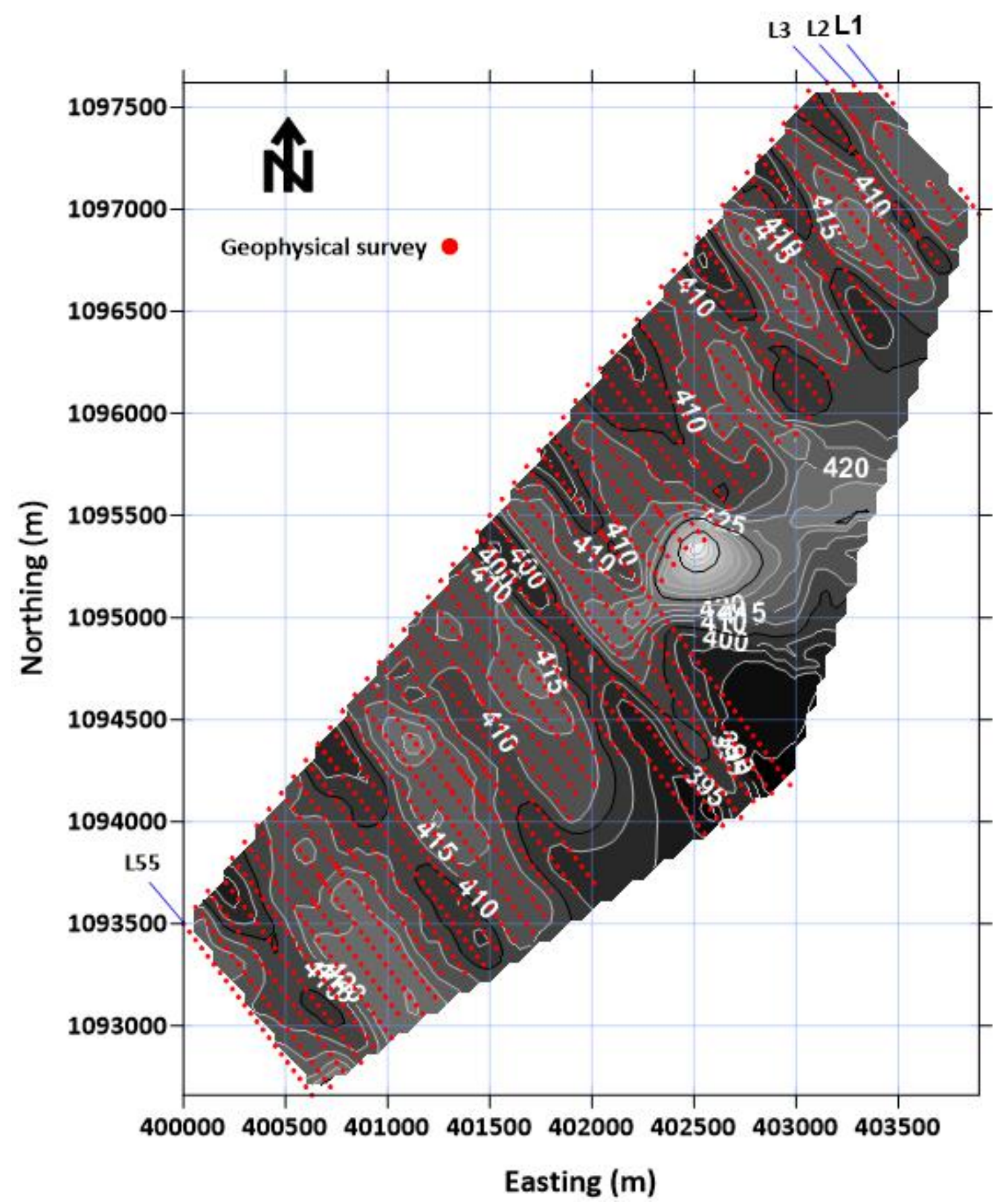

Figure 5. SFP survey map

\subsection{Method: the Sponctaneous frequency polarization (SFP)}

\section{$>$ Principle}

The PSF method is an electrical method which uses as a current source, telluric or natural currents which circulate in the subsoil. As the direct current electrical method, it is based on the Ohm's law V = RI [1]. In practice, using two electrodes grounded at points $\mathrm{A}$ and $\mathrm{M}$, the potential difference $\mathrm{V}$ generated between these electrodes by the telluric or natural currents passing through the subsoil formations is measured by selection of frequency. Measuring the 
natural electric field at the surface $(<50 \mathrm{~m})$ at $\mathrm{N}$ selected frequencies composing said field, enables to measure the electrical responses of lithological bodies $[1,8]$.

\section{$>$ Theoretical concept}

The electric potential $U(s)$ at a point due to a point source of current on a subsoil layer was described by Stefanescu in 1930 [9] is given by:

$$
U(s)=\frac{I}{2 \pi} \int_{0}^{\infty} T(\lambda) J_{0} \lambda s d \lambda
$$

$\mathrm{J}_{0}(\lambda \mathrm{s})$ is the zero-order Bessel function of the first type; $\mathrm{T}(\lambda)$ is the electrical impedance at the surface defined by [10] as the transform function of resistivities and layer thicknesses; $\lambda$ is the integration variable.

Koefoed also dissociated the transform function of resistivity $T(\lambda)$ to extract the Kernel function of resistivity $\mathrm{K} 1(\lambda)$ representing the deviation of a homogeneous half-space of a subsoil layer [11]. Consequently, at the air-earth interface, we have:

$$
T_{1}(\lambda)=\rho_{1}\left[1+2 K_{1}(\lambda)\right]
$$

And for several layers laminated from the surface to the i-th layers, we have:

$$
T_{i}(\lambda)=\rho_{i}\left[1+2 K_{i}(\lambda)\right]
$$

From these basic expressions, Das and Verma obtained an expression of the electric potential $\mathrm{U}(\mathrm{s})$ as a function of the apparent resistivity $\rho \mathrm{a}(\mathrm{s})$ for a system of two electrodes $\mathrm{A}$ and $\mathrm{M}$ [9]:

$$
U(s)=\frac{I}{2 \pi s} \rho_{a}(s)
$$

$\mathrm{S}=\mathrm{AM}$ the distance between the two electrodes $\mathrm{A}$ and $\mathrm{M}$

The equation (4) shows that the potential $U$ (s) and the apparent resistivity pa (s) are proportional. Therefore, they translate the same electrical characteristics of the subsoil layers for a constant current I.

The aforementioned source of electric current has: an artificial origin (comes from an energy accumulator) and a natural origin (comes from atmospheric or natural phenomena of the terrestrial globe). For an artificial source, a constant current I is delivered by an accumulator and injected into the ground. This yields an expression of the potential $U$ (s) according to equation (1). This case relates to the direct current electrical method [9].

For a natural source, the current I originates from atmospheric or natural phenomena of the terrestrial globe and circulates in the subsoil at a certain frequency. This current $\mathrm{I}$ is then 
frequency-dependent $(I=\mathrm{f}$ (frequency) $)$ and called telluric current $[1,8,12]$. The theory of the telluric currents method is that, within limits of small areas of the earth's surface, the field of telluric currents at any given instant can be thought of as a constant current field, created by an infinite long power line [1]. As the studied medium is assumed to be uniform in a horizontal direction, then such a field is everywhere constant in value and direction. Hence, I $=\mathrm{f}$ (frequency) is constant. We thus find the expression of the potential $\mathrm{U}$ (s) according to equation (1). In this case, we call of the electro-telluric method or the spontaneous frequency polarization method [12].

\section{$>$ Penetration depth}

The depth of penetration of telluric currents depends on their frequency and the resistivity of the overlying stratigraphic column. It is expressed by the equation $5[1,12]$ :

$$
h=\frac{1}{2} \sqrt{\frac{\rho_{a}}{f}}
$$

Where $\mathrm{h}$ is the depth in $\mathrm{km}$; $\mathrm{f}$ is the frequency in hertz; $\rho$ is the resistivity in Ohm.m.

Assuming a constant resistivity (available by calibration with existing electrical logs), frequency and depth are directly related $[1,12,13]$. Thus, when acquiring geophysical data with the PQWT500 equipment of the Hunan Puqi Institute, band-pass filters are used to select telluric currents at a specific range of frequencies or depths. This selection of telluric currents through their frequency at the surface (less than $50 \mathrm{~m}$ ), allows an investigation at well-defined depths [8]. For the PQWT devices particularly, the depth of investigation is obtained automatically via inversion software integrated into the device's operating circuit [8].

\section{Results and Discussion}

\subsection{Results}

\section{Electrical gradient (ddp) profiles}

The electrical gradient (ddp) profiles shown in Figures 6, 7 and 8 correspond to the electrical profiling along the L3, L4, L5, L6, L11, L12, L13, L14, L49, L50, L51 and L52 traverses. They were plotted using Microsoft Office Excel 2016. They cover a superficial investigation programmed when taking data from the Three-frequency module of the PQWT500. They would thus provide quantitative information on the lateral variations of the electrical contrasts of surface formations. The location of a point on the profile is given by the abscissa $\mathrm{x}(\mathrm{m})$. 
The calibration of the electrical responses of marble, schist and quartzite formations observed in the field and researches of some authors $[1,12,14]$ permit to have characteristic ranges of values of the electrical gradients of marble-type, schist-type and quartzite-type formations of the study area. It appears that the schist have low electrical gradients (ddp $<3 \mathrm{mV}$ ). Marbles and quartzites exhibit high electrical gradients with values between 3 and $15 \mathrm{mV}$. Quartzites are very unrepresentative in the study area. Their identification during data collection is easy and allows them to be systematically classified in the group of sterile formations or those with low electrical gradients during data processing. Thus, the analysis and interpretation of electrical gradient profiles consist in systematically identifying areas of electrical contrasts which mainly characterize marble formations. This location made it possible to underline between $\mathrm{x}=200 \mathrm{~m}$ and $\mathrm{x}=400 \mathrm{~m}$, around $\mathrm{x}=425 \mathrm{~m}$, between $\mathrm{x}=650$ $\mathrm{m}$ and $\mathrm{x}=800 \mathrm{~m}$ and between $\mathrm{x}=900 \mathrm{~m}$ and $\mathrm{x}=950 \mathrm{~m}$, the presence of marble-type formations ( $\mathrm{ddp}>3 \mathrm{mV}$ ) for the profile L3 (Figure 6a). Likewise, marble-type formations $(\mathrm{ddp}>3 \mathrm{mV})$ are identified between $\mathrm{x}=250 \mathrm{~m}$ and $\mathrm{x}=400 \mathrm{~m}$, between $\mathrm{x}=650 \mathrm{~m}$ and $\mathrm{x}=$ $800 \mathrm{~m}$ and around $\mathrm{x}=875 \mathrm{~m}$ for the profile L4 (Figure 6b); around $\mathrm{x}=200 \mathrm{~m}$, between $\mathrm{x}=$ $250 \mathrm{~m}$ and $\mathrm{x}=400 \mathrm{~m}$, around $\mathrm{x}=425$, between $\mathrm{x}=650 \mathrm{~m}$ and $\mathrm{x}=850 \mathrm{~m}$ and around $\mathrm{x}=900$ $\mathrm{m}$ for the L5 profile (Figure 6c); around $\mathrm{x}=200 \mathrm{~m}$, between $\mathrm{x}=250 \mathrm{~m}$ and $\mathrm{x}=400 \mathrm{~m}$, around $\mathrm{x}=775 \mathrm{~m}$ and $\mathrm{x}=875 \mathrm{~m}$ for profile L6 (Figure $6 \mathrm{~d}$ ). Moreover, apart from the abovementioned zones, the electrical profiles L3, L4, L5, and L6 (Figure 6) mainly cross schist-like formations characterized by low electrical gradients $(\mathrm{ddp}<3 \mathrm{mV})$.

For the electrical profiles L11, L12, L13, and L14 (Figure 7) the areas of strong electrical gradients $(\mathrm{ddp}>3 \mathrm{mV})$ are observed around $\mathrm{x}=450 \mathrm{~m}$ and around $\mathrm{x}=600 \mathrm{~m}$ for the profile L11 (Figure 7a $-b$ ) and the profile L12, respectively; around $\mathrm{x}=250 \mathrm{~m}$ and $\mathrm{x}=450 \mathrm{~m}$ for the profile L13 (Figure 7c); around $x=475 \mathrm{~m}$ and $\mathrm{x}=675 \mathrm{~m}$ for the profile L14 (Figure 7d). These areas mainly characterize marble-like formations. In addition, the schist or sterile rock formations, characterized by low electrical gradients $(\mathrm{ddp}<3 \mathrm{mV})$, are located between $\mathrm{x}=0$ $\mathrm{m}$ and $\mathrm{x}=400 \mathrm{~m}$, between $\mathrm{x}=500 \mathrm{~m}$ and $\mathrm{x}=550 \mathrm{~m}$ and between $\mathrm{x}=650 \mathrm{~m}$ and $\mathrm{x}=1000 \mathrm{~m}$ for profiles L11 and L12 (Figures 7a-b); between $\mathrm{x}=0 \mathrm{~m}$ and $\mathrm{x}=200 \mathrm{~m}$, between $\mathrm{x}=300 \mathrm{~m}$ and $\mathrm{x}=400 \mathrm{~m}$ and between $\mathrm{x}=600 \mathrm{~m}$ and $\mathrm{x}=1000 \mathrm{~m}$ for the profileL13 (Figure 7c); between $\mathrm{x}=0 \mathrm{~m}$ and $\mathrm{x}=450 \mathrm{~m}$, between $\mathrm{x}=500 \mathrm{~m}$ and $\mathrm{x}=650 \mathrm{~m}$ and between $\mathrm{x}=700 \mathrm{~m}$ and $\mathrm{x}=1000 \mathrm{~m}$ for the profiles L14 (Figure 7d).

Profiles L49, L50, L51 and L52 (Figure 8) cross an electrically disturbed basement. The strong electrical gradients $(\mathrm{ddp}>3 \mathrm{mV})$ are located only between $\mathrm{x}=450 \mathrm{~m}$ and $\mathrm{x}=500 \mathrm{~m}$, and between $\mathrm{x}=850 \mathrm{~m}$ and $\mathrm{x}=900 \mathrm{~m}$ for the profile L49 (Figure 8a); between $\mathrm{x}=850 \mathrm{~m}$ 
and $\mathrm{x}=900 \mathrm{~m}$ for the profile L50 (Figure 8b); around $\mathrm{x}=550 \mathrm{~m}$, and between $\mathrm{x}=850 \mathrm{~m}$ and $\mathrm{x}=900 \mathrm{~m}$ for profile L51 (Figure $8 \mathrm{c}$ ); around $\mathrm{x}=600 \mathrm{~m}$, and around $\mathrm{x}=850 \mathrm{~m}$ for profile 52 (Figure 8d). On the other hand, the low electrical gradients (ddp $<3 \mathrm{mV}$ ) are located: between $\mathrm{x}=0 \mathrm{~m}$ and $\mathrm{x}=400 \mathrm{~m}$, between $\mathrm{x}=550 \mathrm{~m}$ and $\mathrm{x}=800 \mathrm{~m}$ and between $\mathrm{x}=950 \mathrm{~m}$ and $\mathrm{x}=1150 \mathrm{~m}$ for the profile L49 (Figure 8a); between $\mathrm{x}=0 \mathrm{~m}$ and $\mathrm{x}=800 \mathrm{~m}$ and between $\mathrm{x}=950 \mathrm{~m}$ and $\mathrm{x}=1200 \mathrm{~m}$ the profile L50 (Figure 8b); between $\mathrm{x}=0 \mathrm{~m}$ and $\mathrm{x}=500 \mathrm{~m}$, between $\mathrm{x}=600 \mathrm{~m}$ and $\mathrm{x}=800 \mathrm{~m}$ and between $\mathrm{x}=950 \mathrm{~m}$ and $\mathrm{x}=1200 \mathrm{~m}$ for profile L51 (Figure 8c); between $\mathrm{x}=0 \mathrm{~m}$ and $\mathrm{x}=550 \mathrm{~m}$, between $\mathrm{x}=650 \mathrm{~m}$ and $\mathrm{x}=800 \mathrm{~m}$ and between $x=900 \mathrm{~m}$ and $\mathrm{x}=1200 \mathrm{~m}$ for the profile L52 (Figure 8d).

Ultimately, results from the electrical profiles shows that more than $95 \%$ of profiles present electrical contrasts characterizing electrical discontinuities $[1,7]$. Indeed, these discontinuities materialize the contact areas between marbles - schist (or sterile) or schist (or sterile) marbles. The high electrical gradients $(\mathrm{ddp}>3 \mathrm{mV})$ and low electrical gradients $(\mathrm{ddp}<3 \mathrm{mV})$ characterize marbles and schist (or sterile rocks), respectively. These discontinuities are longitudinal in the NW-SE direction of the profiles. 


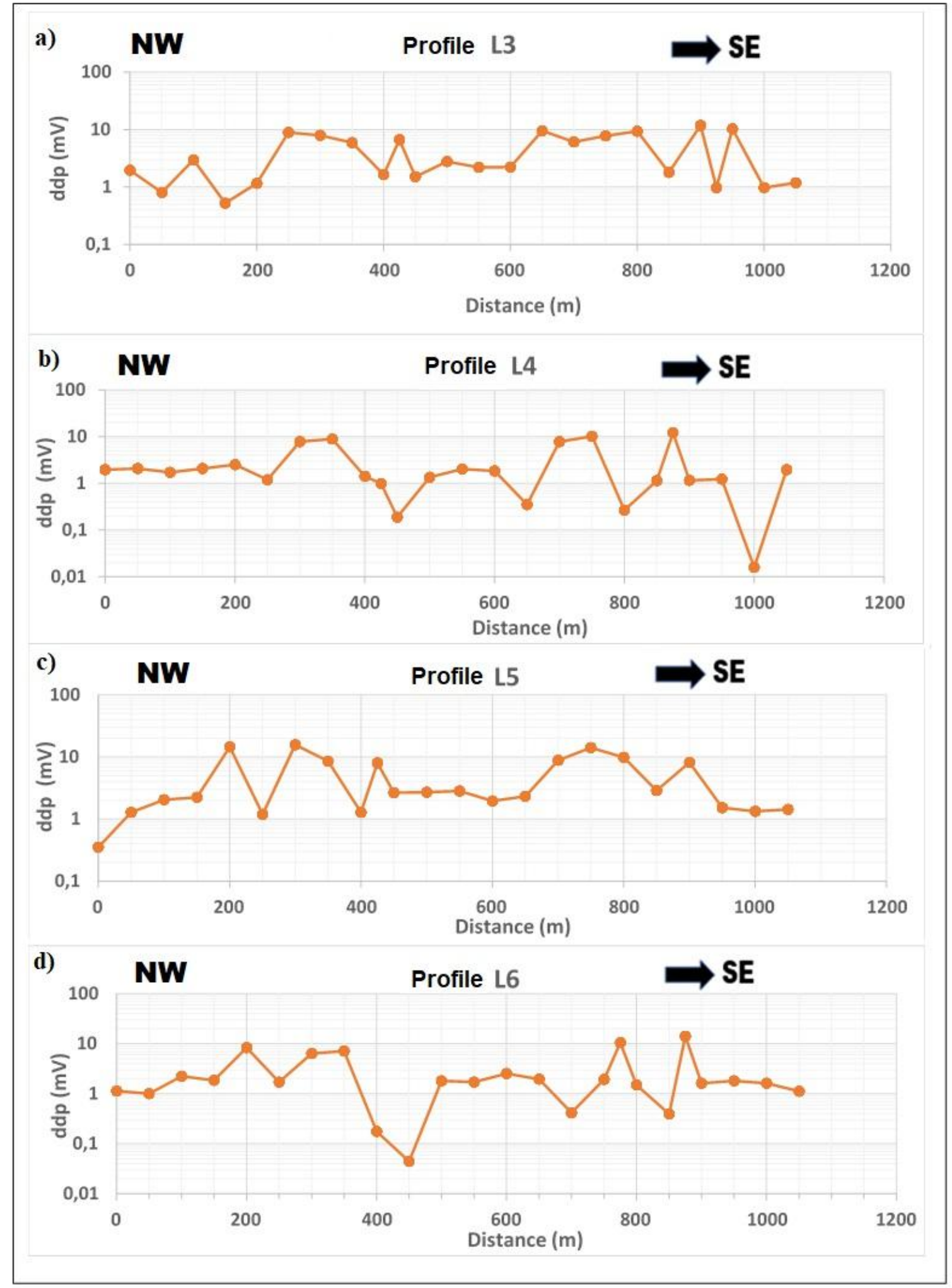

Figure 6. SFP profiling of profiles L3 (a), L4 (b), L5(c) and L6 (d) 


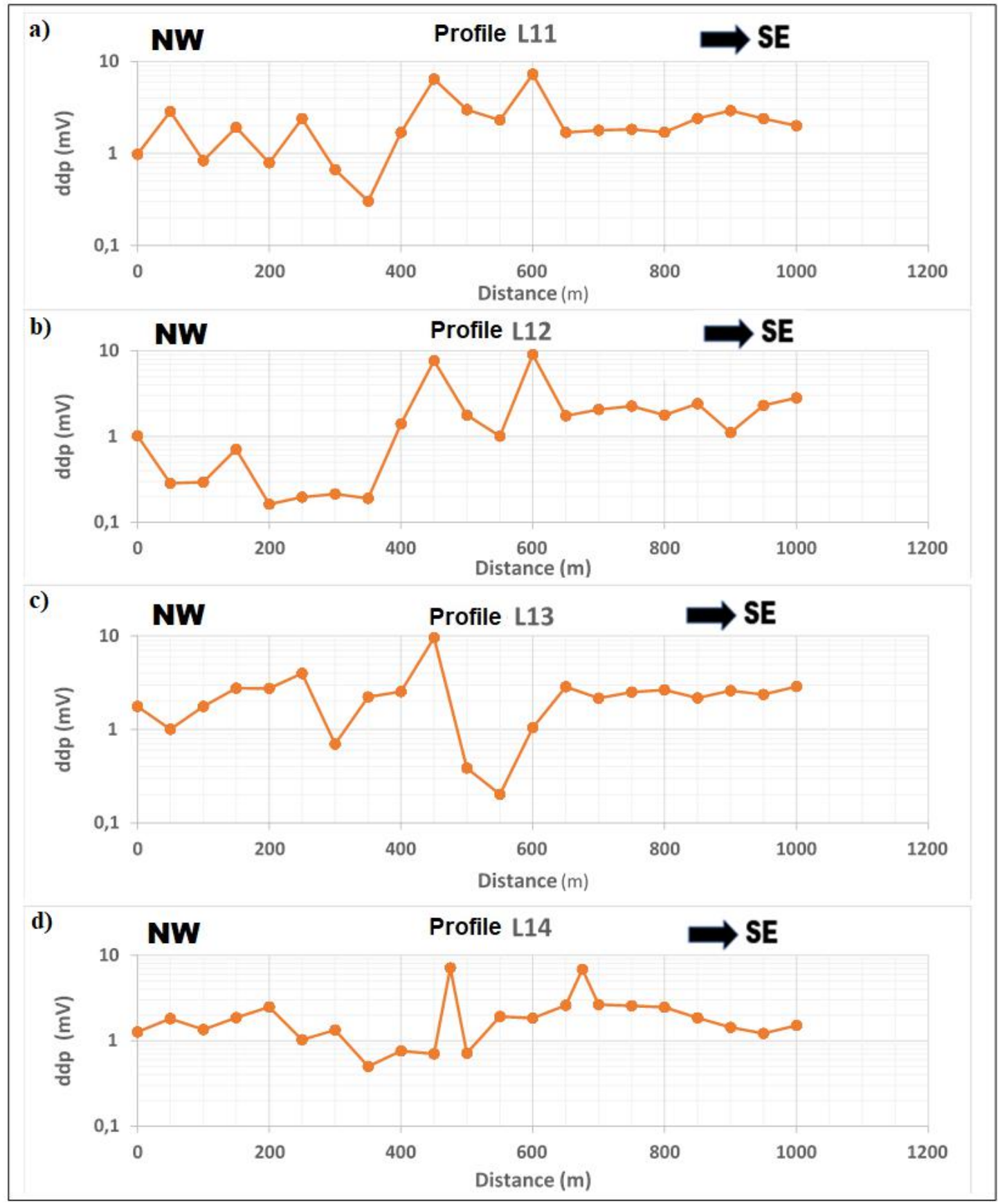

Figure 7. SFP profiling of profiles L11 (a), L12 (b), L13 (c) and L14 (d) 


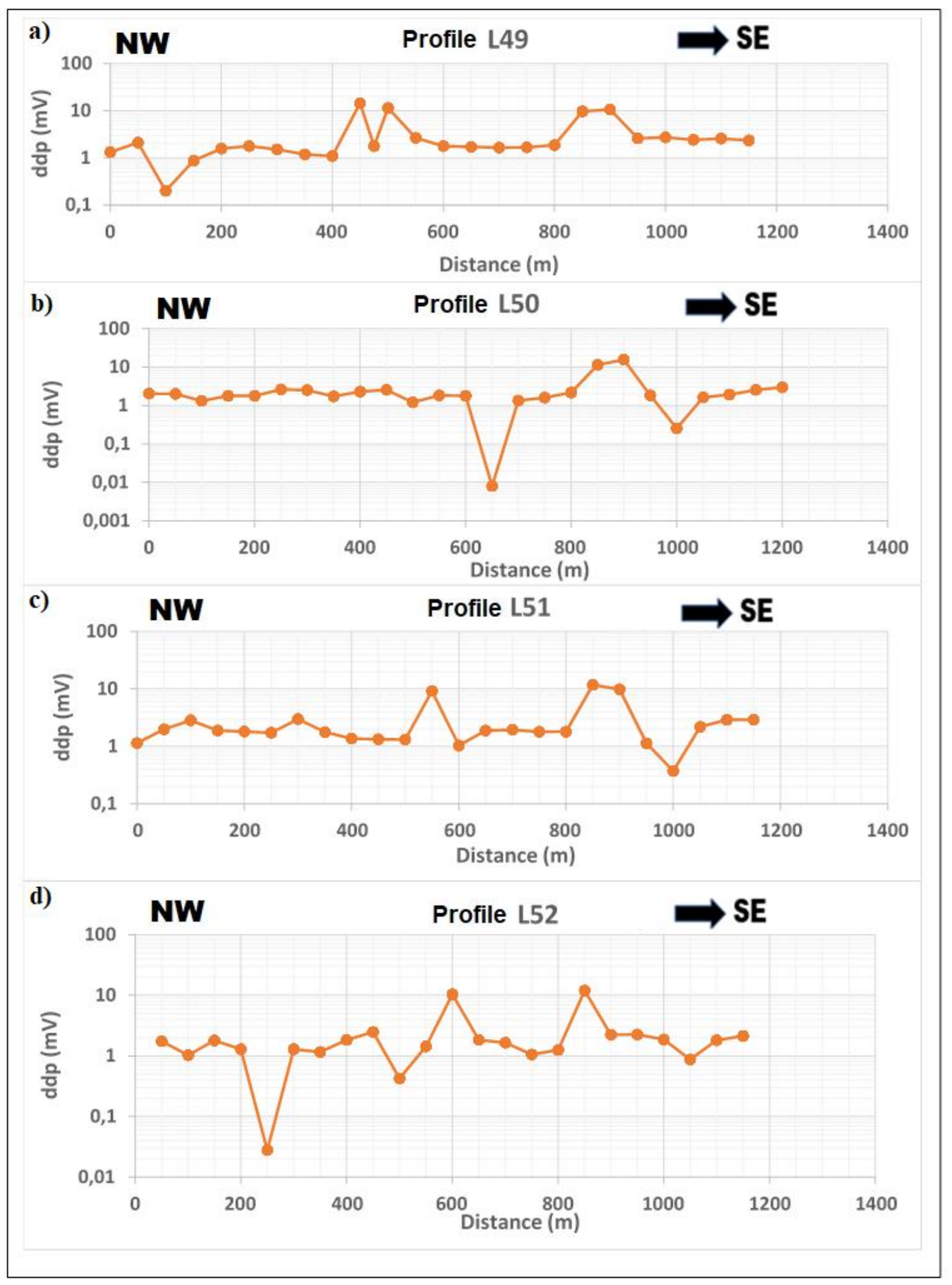

Figure 8. SFP profiling of profiles L49 (a), L50 (b), L51 (c) and L52 (d) 


\section{$>\quad$ SFP map}

The electrical profiling data collected along the lines enabled to produce a map of electrical gradients by interpolation with the Surfer software (Golden Software, 2016). It represents the iso-value curves of the electrical gradients of surface formations (Figure 9). It allows the observation of the electric field distributions of the study area $[1,7,14]$.

Observation of the electrical gradient map (Figure 9) shows that the high electrical gradients structures (ddp $>3 \mathrm{mV}$, green to yellow colours) are located mainly along the NE-SW direction in the south, north and centre of the study area. They alternate in the NW-SE direction with formations characterized mainly by low electrical gradients (ddp $<3 \mathrm{mV}$, blue colours). In view of the aforementioned information, in support of the geological reconnaissance work in the field and the work of several authors $[1,7]$, it emerges that these high electrical gradients $(\mathrm{ddp}>3 \mathrm{mV})$ structures are identified as marble formations while those with low electrical gradients $(\mathrm{ddp}<3 \mathrm{mV})$ matched with schist or sterile formations. The marbles evolve along the NE-SW direction corridors. This strike is sometimes intercepted by schist (Figure 9). The marble - schist (or sterile) or schist (or sterile) - marble transition zones materialize areas of electrical discontinuities of the metasedimentary formations in the study area. 


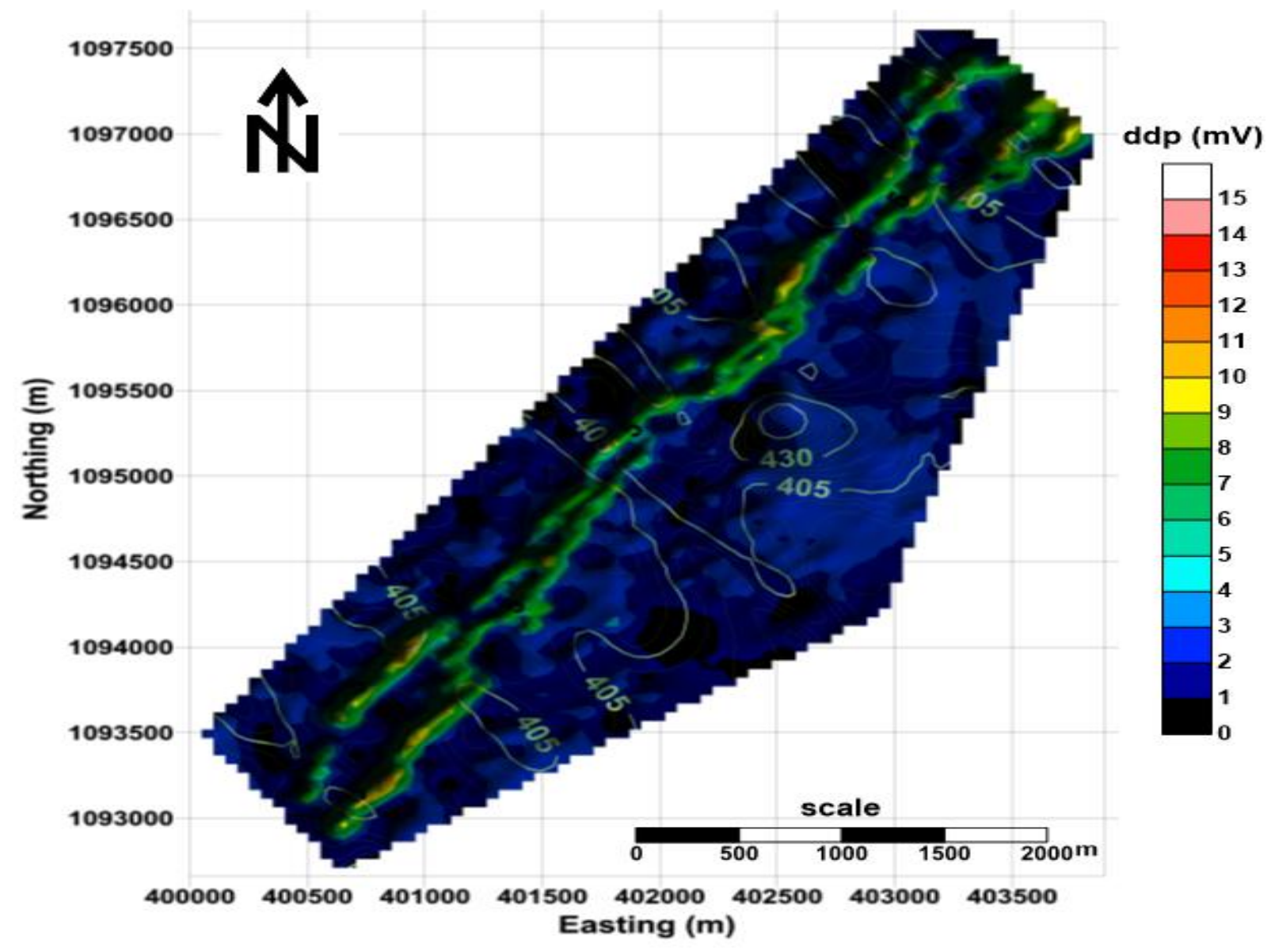

Figure 9. SFP map of the study area

The comparison of the electric gradient map (ddp) with the existent geological map shows a perfect correlation of the electrical responses (ddp) with the geological formations of the study area (Figure 10). Also, the borehole data in the high electrical area or green colour responses (Figure 11) show the presence of marble formations mainly. The above information undeniably attest that the marble formations, characterized by high electrical responses (ddp $>3 \mathrm{mV}$, green to yellow colours), alternate with schist (or sterile) formations, characterized by low electrical responses ( $d d p<3 \mathrm{mV}$, blue colours). This confrontation brings out also the discontinuity of the marble corridors in the NE-SW direction. 


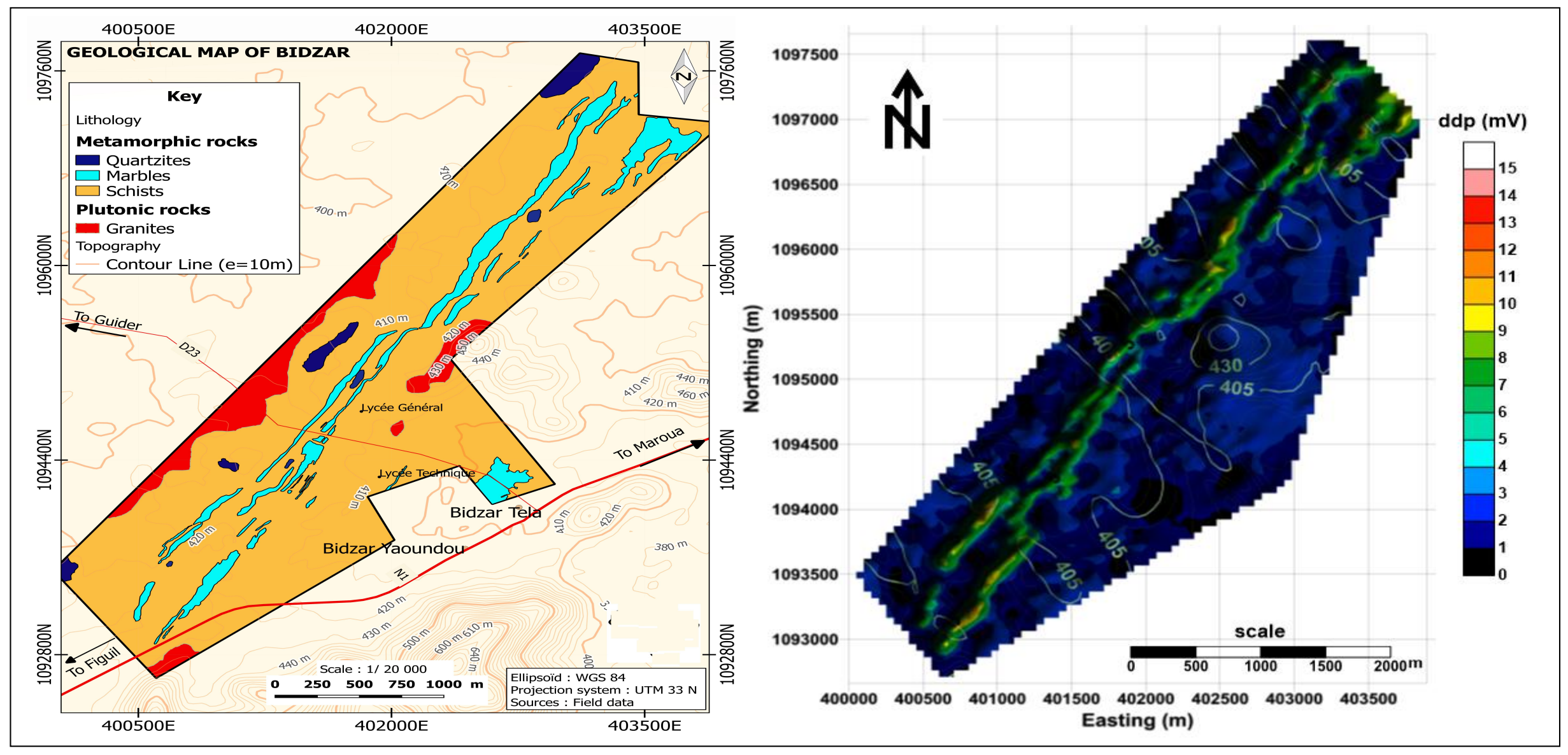

Figure 10. Correlation map between SFP data and geological data of the study area 


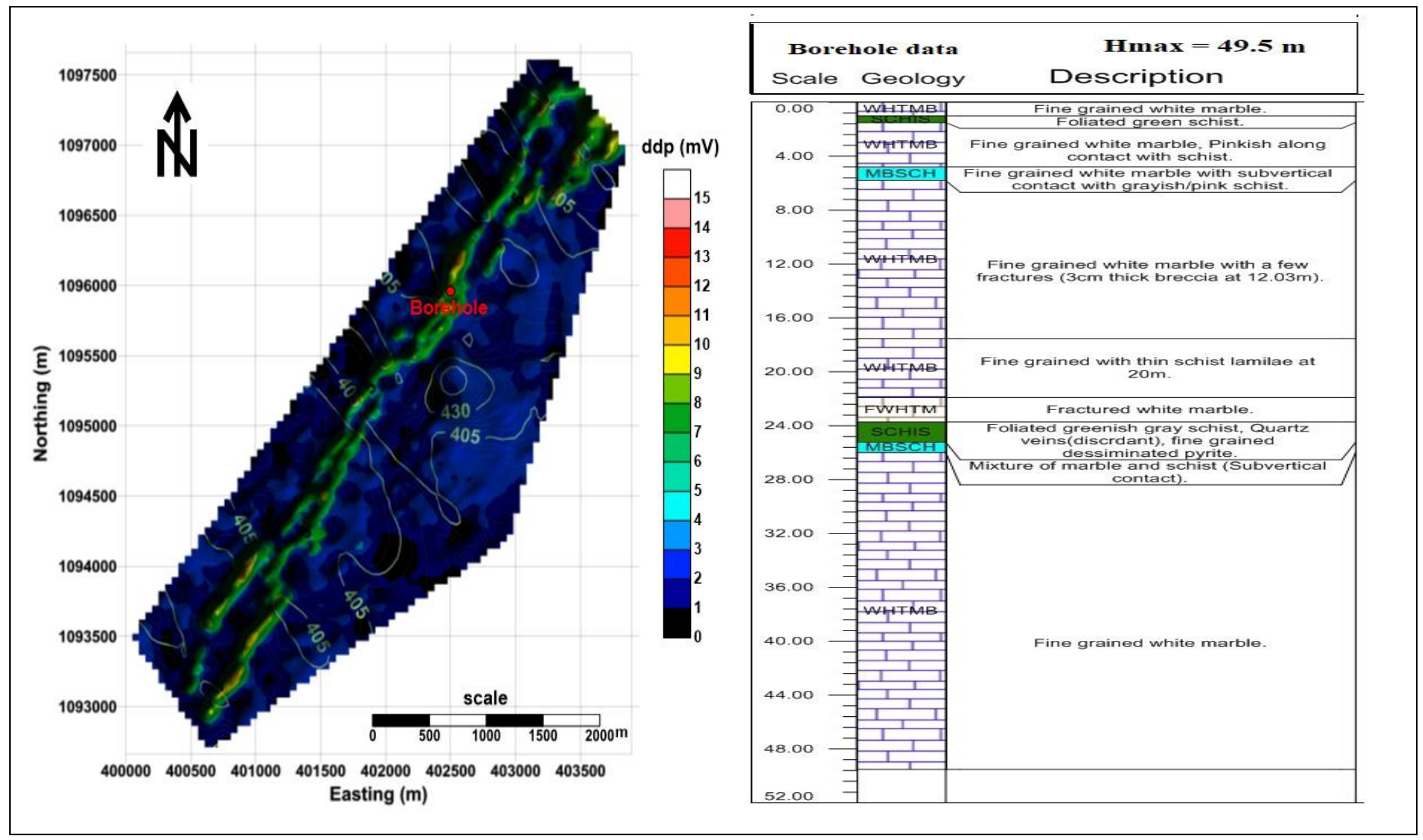

Figure 11. Correlation map between SFP data and borehole data of the study area 


\subsection{Discussion}

The geological context of the Nord Cameroon region shows that the study area would have experienced an intense tectonic activity marked by the passage from a sub-horizontal dip to a sub-vertical dip [3]. This dip reflects a vertical straightening and a lateral alternation of layers. Analyzes and interpretations of the results of the electrical gradient profiles reveal a diversity of electrical discontinuities along the profiles characterized by the passage from strong electrical gradients (ddp $>3 \mathrm{mV})$ to low electrical gradients $(\mathrm{ddp}<3 \mathrm{mV})$ and vice versa [1, 14]. More than $95 \%$ of the profiles have electrical discontinuities. This plurality of discontinuities emanates from the alternation between marble formations (characterized by high electrical gradients $(\mathrm{ddp}>3 \mathrm{mV}))$ and massive schist or sterile formations characterized mainly by low ddp values $\quad(<3 \mathrm{mV})[1,13]$. This alternation evolves in the NW-SE direction.

Besides, analyzes and interpretations of the electrical gradient map also reveal that the structures of high electrical gradients (ddp $>3 \mathrm{mV}$, green to yellow colors) alternate with structures of weak electrical gradients (ddp $<3 \mathrm{mV}$, blue colors). These structures characterize respectively the marble formations and the schist or sterile formations $[1,14]$. Also, these results show that the evolution of marble is lenticular and discontinuous along NE-SW directed corridors, transverse to the direction of profiles $[15,16]$.

Geophysics is an indirect method whose results are only confirmed or verified by a direct method such as geology $[15,16]$. Thus, to confirm the above-mentioned results, the map of electrical gradients (ddp) of this study was compared with the geological and borehole data from geological studies. This comparison shows a perfect correlation of the electrical responses (ddp) with the geological formations of the study area (Figures $10 \& 11)$. It consequently confirms the efficiency of the electro-telluric or spontaneous frequency polarization (SFP) method in the mapping of the marble corridors of Bidzar (Figure 9) in North Cameroon (Central Africa).

\section{Conclusion}

Electrical gradient (ddp) surveys were carried out on the marble ore of Bidzar located in north-east of Garoua (capital of the North Cameroon region, Central Africa). The geophysical instrument is the PQWT500 which uses the natural current electric method. The results obtained (profiles and map of electrical gradients) come from the electrical profiling. Analyzes and interpretations made through the different forms of representations obtained by 
2D modelling highlighted several zones of electrical discontinuities which are identified relatively to the contact or transition zones of marbles and schist. Marbles are characterized by high electrical gradients ( $\mathrm{ddp}>3 \mathrm{mV}$ ) and schist or sterile rock are characterized by weak electrical gradients ( $d \mathrm{dp}<3 \mathrm{mV}$ ). The target electrical responses, i.e. high electrical gradients, enabled corridors of the Bidzar marble ore to be effectively mapped. These corridors are discontinuous and evolve along the NE-SW direction. They alternate with schist formations following the NW-SE direction. The comparison of these results with the geological data from previous geological studies (hammer prospecting) and borehole data, comfort the outputs of this study, and mitigate the ambiguity on the potentiality of the electric method with natural current or spontaneous frequency polarization in the mapping of marble ores. Therefore, it emerges that the spontaneous frequency polarization method would occupy a preponderant place in the mapping of mineral resources in metasedimentary formations, mainly that of marble.

\section{Acknowledgements}

The authors are grateful to the reviewers for their kind remarks making the manuscript clearer and more pertinent. The authors are also grateful to the Artisanal and Small Scale Unit of the Ministry of Mines, Industry \& Technological Development for providing the PQWT500 geoelectrical device from the Hunan Puqi Institute (China) instrument to collect the data sets on site.

\section{References}

[1] Telford, W. M., Geldart, L. P., Sheriff, R. E., Keys, D. A. (1990) Applied geophysics 2th edition, Cambridge University press, $770 \mathrm{p}$.

[2] Toteu, S. F, Van Schmus, W. F., Penaye J. P. and Michard A. (2001) New U-Pb and Sm$\mathrm{Nd}$ data from north-central Cameroon and its bearing on the pre-Pan-African history of central Africa, Precambrian Res. 108, pp. 45-73.

[3] Ndjeng, E. (1998) Les structures sédimentaires du bassin de Babouri-Figuil (fossé de la Bénoué) dans le Nord-Cameroun. Géosciences au Cameroun, Vicat J.P. et Bilong P. éd., collect. GEOCAM, Press. Univ. Yaoundé I., pp. 149-156.

[4] Ngounouno, B. Déruelle, R. Guiraud, J. P. and Vicat, (2001) Magmatismes tholéiitique et alcalin des demi-grabens crétacés de Mayo Oulo-Léré et de Babouri-Figuil (Nord du 
Cameroun-Sud du Tchad) en domaine d'extension continentale, C. R. Acad. Sci.Paris, Ser. IIa 333 (2001) PP 201-207.

[5] Dawaï, D. (2014) Les plutons de Guider et de Bossoum-Pologozom (chaîne panafricaine au Nord-Cameroun) : analyses pétrographique, structurale, magnétique, géochronologique et implications géodynamiques. Thèse de Doctorat, Page 195.

[6] Vallerie, M., (1964). Feuilles Bidzar et Guider Ed 1964 p. (10-11)

[7] Keary, P. and Brooks, M. (1991). An Introduction to Geophysical Exploration. Blackwell Scientific Publications, $2^{\text {nd }}$ ed, $254 \mathrm{p}$.

[8] PQWT publications, videos (http://www.pqwtcs.com/NewsDetail.aspx?nid $=3643 \&$ classid $=273) \&$ website http://www.pqwtcs.com $/$.

[9] Das, U.C. and Verma, S. K. (1980) Digital Linear Filter for Computing Type Curves for the Two-Electrode System of Resistivity Sounding, Geophysical Prospecting 28, 610-619.

[10] Koefoed, O. (1970). A fast method for determining the layer distribution from the raised kernel function in geoelegtrical sounding. Geophysical Prospecting, 18(4), 564-570. doi:10.1111/j.1365-2478.1970.tb02129x

[11] Koefoed, O. (1979) Resistivity Sounding Measurements, Ser. Methods in Geochemistry and Geophysics 14A, Geosounding Principles 1. Elsevier, Amsterdam Oxford-New York, $276 \mathrm{p}$

[12] Zagarmistr, A. M. and Berdichevskiy, M. N. (1959). Electrical prospecting by the telluric currents method. Petroleum Geology: A digest of Russian literature on Petroleum Geology, Vol. 3, No. 1B., pp. 40-49

[13] Liao X, Cheng H and Bai Y, (2012). Design and Application of Natural Audio Electric Field Frequency Selecting Instrument. Applied Mechanics and Materials Vol. 103, pp 1519.

[14] Cheng H., Di Q. Y. and Li D. Q. (2010) The discussion electrical properties of rocks base on frequency characteristics. Progress in Geophy. (In Chinese), 25(3): 918-925.

[15] Dorbath, C. (1979) Prospection géophysique des cipolins de bandafassi (sénégal oriental). ORSTOM, Géophys., no 16: 35-46.

[16] Palacky, G. J. (1989) Resistivity characteristics of geologic targets, In MN Nabighian, Ed, electromagnetic methods in Applied Geophysics, vol. 1 (theory) IG, No 3, Society of Exploration Geophysics, pp. 53-129. 